\title{
Crystallization and Crystalline Structure of Syndiotactic Polypropylene and Syndiotactic-Poly(1-Butene) Blend
}

\author{
Naofumi Naga1 ${ }^{*}$, Yuuki Takagi ${ }^{1}$, Shogo Urakami1 ${ }^{1}$ Keiichi Noguchi² \\ ${ }^{1}$ Department of Applied Chemistry, Material Science Course, College of Engineering, Shibaura Institute of \\ Technology, Tokyo, Japan \\ ${ }^{2}$ Instrumentation Analysis Center, Tokyo University of Agriculture and Technology, Tokyo, Japan \\ Email: nnaga@sic.shibaura-it.ac.jp
}

Received 15 August 2014; revised 16 September 2014; accepted 27 September 2014

Copyright (C) 2014 by authors and Scientific Research Publishing Inc.

This work is licensed under the Creative Commons Attribution International License (CC BY). http://creativecommons.org/licenses/by/4.0/

(c) O) Open Access

\section{Abstract}

The crystallization and crystalline structure of syndiotactic-polypropylene (sPP) and syndiotactic-poly(1-butene) (sPB) blend containing 10 (Bl-10), 25 (Bl-25), 50 (Bl-50), 75 (Bl-75), and 90 (Bl-90) wt\% of sPB, have been investigated by means of differential scanning calorimetry (DSC), FT-IR, and wide-angle X-ray diffraction (WAXD) analyses. The melt-crystallization behavior of the blend samples was studied by DSC on the cooling process at constant rates. Bl-50, Bl-75, and Bl-90 showed lower crystallization temperatures than the neat SPP. sPP in BI-75 showed the lowest crystallization rate among the blend samples. Bl-90 showed a two-phase molten state, and sPP in Bl-90 crystallized via two-stepprocess. Time evolution of FT-IR spectroscopy at room temperature detected conformational transformation of the sPP polymer chain in the blend samples of Bl-50 and BI-75. The absorption peaks intensity in the FT-IR spectra derived from the helical conformations in the crystalline phase decreased, and the planar zigzag conformations in the amorphous and mesophase phases decreased over the crystallization time. The time evolution of the WAXD profile of Bl-90 indicated that SPP in the blend accelerated the crystallization of SPB. The crystallized $\mathrm{Bl}-10, \mathrm{Bl}-25$, and $\mathrm{Bl}-50$ samples showed diffraction peaks in WAXD profiles and melting endothermic peak in DSC profiles derived from only the SPP crystal. The crystallinity and melting temperature of SPP in the crystallized $\mathrm{Bl}-10, \mathrm{Bl}-25$, and $\mathrm{Bl}-50$ samples were almost independent of the sPB content. Both the crystalline structure of sPP and SPB were detected in Bl-75 and Bl-90. Bl-75 showed the lowest crystallinity and melting temperature of SPP among the blend samples.

\section{Keywords}

Syndiotactic-Polypropylene, Syndiotactic-Poly(1-Butene), Blend, Crystallization

\footnotetext{
*Corresponding author.
}

How to cite this paper: Naga, N., et al. (2014) Crystallization and Crystalline Structure of Syndiotactic Polypropylene and Syndiotactic-Poly(1-Butene) Blend. Open Journal of Polymer Chemistry, 4, 102-114. 


\section{Introduction}

Development of transition metal catalysts for olefin polymerizations has enabled us to synthesize highly syndiotactic poly( $\alpha$-olefin)s with narrow molecular weight and composition distributions [1]. The syndiotactic-poly ( $\alpha$-olefin)s, such as polypropylene (sPP), poly(1-butene) (sPB), poly(1-pentene), poly(1-hexene), poly(1-octene), poly(4-methyl-1-pentene), and poly(4-methyl-1-hexene), are of the polymers that can be obtained with Cssymmetrical syndio-selective metallocene catalysts [2] [3]. The crystalline structures of some the syndiotaticpoly ( $\alpha$-olefin)s, sPP [4]-[14], sPB [15]-[17], poly(1-pentene) [18], and poly(4-methyl-1-pentene) [19] [20] have been reported.

The Cs-symmetrical syndio-selective metallocene catalysts also promote copolymerization of olefins effectively. The copolymerization of propylene with other olefins is one of the useful methods to control the crystalline structure and properties of sPP [20]-[32]. The syndiotactic-poly(propylene-co-olefin)s (olefin = ethylene, 1-butene, 1-pentene, 1-hexene, and 4-methyl-1-pentene) were synthesized by a syndio-selective zirconocene catalyst, and the crystalline structure of the copolymers were studied [23] [27]. The copolymer with 1-butene showed a smaller melting point depression than the other copolymers with increasing the comonomer content. The 1-butene units in the copolmer expanded the unit cell along $a$ axis with increasing the 1-butene content. A $\left(t_{2} g_{2}\right)_{2}$ conformation in the orthorhombic unit cell of both the sPP and sPB crystals should make possible existance of the 1-butene units in the sPP crystalline phase. This phenomenon is regarded as isomorphism [33].

Polymer blends of sPP with other crystalline polyolefins, such as isotactic-polypropylene (iPP) [34]-[38] or polyethylene [39] [40], have been investigated to modify the properties of sPP. For example, the blend of sPP with iPP increased ductility of sPP. The crystallization conditions strongly affected the crystallization behavior and crystalline structuresof the sPP-iPP blend.

As mentioned above, syndiotactic-poly(propylene-co-1-butene) forms the isomorphous crystal. Both the syndiotactic-poly(propylene-co-1-butene) [41] [42] and iPP-isotactic-poly(1-butene) blend [43] show the isomorphous features. The questions which we would like to consider next are crystallization behavior and crystalline structure of the sPP-sPB blend. In this study, we investigate the crystallization of sPP-sPB blend from melting, and study the effect of SPB content on the crystallization behavior and crystalline structure of the blend samples.

\section{Experimental}

\subsection{Materials}

sPP and sPB were synthesized by polymerization of the corresponding monomer with a syndio-selective zirconocene catalyst, isopropylidene(cyclopentadienyl)(9-fluorenyl)zirconiumdichloride, using methylaluminoxane as a co-catalyst, according to the literature [23]. The number-average molecular weight $\left(M_{\mathrm{n}}\right)$ and molecular weight distribution $\left(M_{\mathrm{w}} / M_{\mathrm{n}}\right)$ of sPP are $M_{\mathrm{n}}=1.98 \times 10^{5} \mathrm{~g} \cdot \mathrm{mol}^{-1}, M_{\mathrm{w}} / M_{\mathrm{n}}=2.1$, and those of sPB are $M_{\mathrm{n}}=5.4 \times$ $10^{5} \mathrm{~g} \cdot \mathrm{mol}^{-1}, M_{\mathrm{w}} / M_{\mathrm{n}}=2.2$. The syndiotacticity of the polymers are high, and the [rrrr] pentad fractions of the polymers are more than 0.9 .

\subsection{Preparation of Polymer Blends}

sPP and sPB (total $1 \mathrm{~g}$ ) were dissolved in a $15 \mathrm{~mL}$ of $o$-dichlorobenzene at $160^{\circ} \mathrm{C}$ and stirred for $30 \mathrm{~min}$. The heated polymer solution was slowly poured into a large excess of methanol with stirring to precipitate the polymer blend. The blend sample was filtered and dried in vacuo at $30^{\circ} \mathrm{C}$ for $6 \mathrm{~h}$. The sPB contents in the blends are 10 (Bl-10), 25 (Bl-25), 50 (Bl-50), 75 (Bl-75), and 90 (Bl-90) wt\%.

\subsection{Analytical Procedures}

The crystallization process was traced with a Rigaku DSC 8230. The blend samples were heated from room temperature to $180^{\circ} \mathrm{C}$ at a heating rate of $10^{\circ} \mathrm{C} / \mathrm{min}$ and kept for $10 \mathrm{~min}$, and cooled to $20^{\circ} \mathrm{C}$ at the desired cooling rate under nitrogen atmosphere. The samples for FT-IR measurement were melted at $200^{\circ} \mathrm{C}$ and pressed under $10 \mathrm{MPa}$ pressure in a mold of $0.2 \mathrm{~mm}$ thickness, and rapidly cooled to room temperature by quenching into water. The IR spectra were measured using a FT-IR 800S (Shimadzu) or a Nexus 470 FT-IR (Thermo Nicolet).

The blend samples were melted at $200^{\circ} \mathrm{C}$ and pressed under $10 \mathrm{MPa}$ pressure in a mold of 5 mm radius with 1 
mm thickness, followed by quenching in water at room temperature. The samples were stored at room temperature for 4 weeks to prepare crystallized samples. The WAXD patterns of the crystallized samples were recorded on a Shimadzu XD-D1 using $\mathrm{Cu} \mathrm{K} \alpha$ radiation. The differential scanning calorimetry (DSC) measurement of the crystallized polymers was investigated by a Shimadzu DSC-50 at a heating rate of $10^{\circ} \mathrm{C} / \mathrm{min}$ from room temperature to $200^{\circ} \mathrm{C}$ under nitrogen atmosphere.

\section{Results and Discussion}

\subsection{Crystallization of SPP in the Blend for Short Period}

The crystallization process of sPP in the blend samples was traced by the DSC measurement from $180^{\circ} \mathrm{C}$ to $20^{\circ} \mathrm{C}$ on the constant cooling rate of $3,6,12$, or $24^{\circ} \mathrm{C} / \mathrm{min}$. Figure 1 shows the DSC profiles of the blend samples on the cooling process at the cooling rate of $3^{\circ} \mathrm{C} / \mathrm{min}$. sPP, Bl-10, and $\mathrm{Bl}-25$ showed an exothermicpeak with a top $\left(T_{\mathrm{c}}\right)$ at $110^{\circ} \mathrm{C}$. Bl-50 or Bl-75 showed the broad exothermic peak with $T_{\mathrm{C}}$ at 108 or $101^{\circ} \mathrm{C}$, respectively. The $T_{\mathrm{C}} \mathrm{S}$ of those samples were lower than that of sPP. Bl-90 showed the bimodal broad exothermic peaks with $T_{\mathrm{C}} \mathrm{S}$ at $108^{\circ} \mathrm{C}$ and $94^{\circ} \mathrm{C}$, indicating formation of two kinds of crystalline structures. The $T_{\mathrm{C}} \mathrm{S}$ of the blend samples detected on all the cooling rates are summarized in Table 1 . The $T_{\mathrm{C}} \mathrm{s}$ of sPP in the blend samples decreased with increasing the cooling rate, as previously repoted about the neat sPP [44]. Bl-50, Bl-75, and Bl-90 showed lower $T_{\mathrm{C}} \mathrm{S}$ than that of the neat sPP. The large a moount of sPB in the blend samples should decrease mobility of the sPP molecules due to the limitation of the occupied volume. The molecular state requires super cooling to crystalize, and decreases the $T_{\mathrm{c}}$ of sPP in those blend samples.

Bl-90 showed the bimodal exothermic peaks in the DSC profiles. A $T_{\mathrm{c}}$ of Bl-90 detected at the higher temperature was almost same to that of the neat SPP. The result indicates that a portion of sPP would form isolate crys-

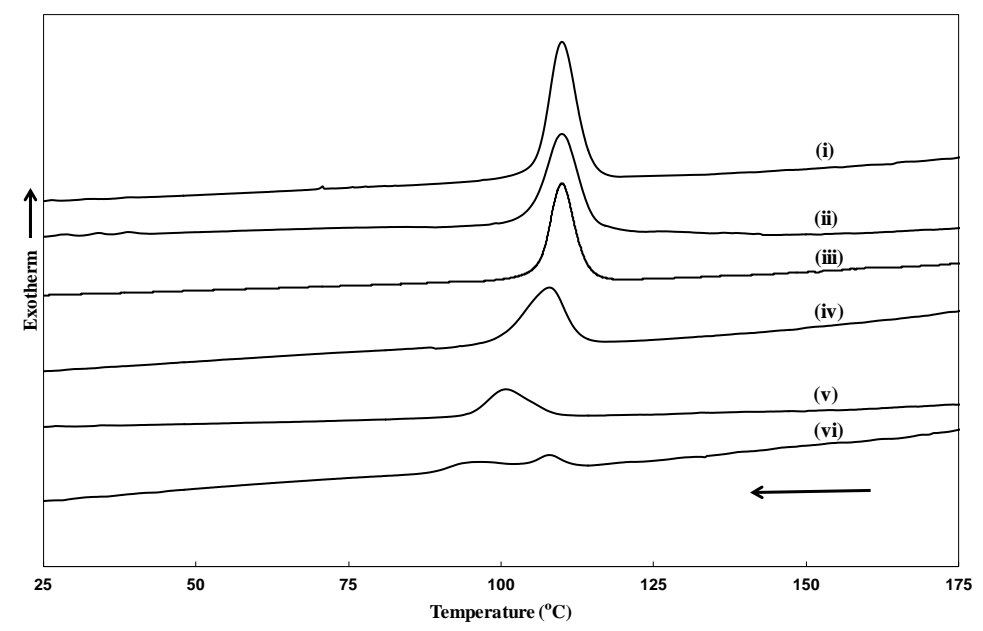

Figure 1. DSC profiles of (i) sPP, (ii) Bl-10, (iii) Bl-25, (iv) Bl-50, (v) Bl-75, and (vi) $\mathrm{Bl}-90$ on the cooling process at a rate of $3^{\circ} \mathrm{C} / \mathrm{min}$.

Table 1. Crystallization temperature $\left(T_{\mathrm{c}}\right)$ and rate of sPP on the constant cooling process.

\begin{tabular}{|c|c|c|c|c|c|c|c|c|c|c|c|c|}
\hline \multirow{2}{*}{$\begin{array}{c}\text { Cooling } \\
\text { rate } \\
{ }^{\circ} \mathrm{C} / \mathrm{min}\end{array}$} & \multicolumn{2}{|c|}{ sPP } & \multicolumn{2}{|c|}{ Bl-10 } & \multicolumn{2}{|c|}{$\mathrm{Bl}-20$} & \multicolumn{2}{|c|}{ Bl-50 } & \multicolumn{2}{|c|}{ Bl-75 } & \multicolumn{2}{|c|}{ Bl-90 } \\
\hline & $\begin{array}{l}T_{\mathrm{c}} \\
{ }^{\circ} \mathrm{C}\end{array}$ & $\begin{array}{c}t_{1 / 2}{ }^{\mathrm{a}} \\
\mathrm{s}\end{array}$ & $\begin{array}{l}T_{\mathrm{c}} \\
{ }^{\circ} \mathrm{C}\end{array}$ & $\begin{array}{c}t_{1 / 2}{ }^{\mathrm{a}} \\
\mathrm{s}\end{array}$ & $\begin{array}{l}T_{\mathrm{c}} \\
{ }^{\circ} \mathrm{C}\end{array}$ & $\begin{array}{c}t_{1 / 2}{ }^{\mathrm{a}} \\
\mathrm{s}\end{array}$ & $\begin{array}{l}T_{\mathrm{c}} \\
{ }^{\circ} \mathrm{C}\end{array}$ & $\begin{array}{c}t_{1 / 2}{ }^{\mathrm{a}} \\
\mathrm{s}\end{array}$ & $\begin{array}{l}T_{\mathrm{c}} \\
{ }^{\circ} \mathrm{C}\end{array}$ & $\begin{array}{c}t_{1 / 2}{ }^{\mathrm{a}} \\
\mathrm{s}\end{array}$ & $\begin{array}{l}T_{\mathrm{c}} \\
{ }^{\circ} \mathrm{C}\end{array}$ & $\begin{array}{c}t_{1 / 2}{ }^{\mathrm{a}} \\
\mathrm{s}\end{array}$ \\
\hline 3 & 110.0 & 3.2 & 110.0 & 3.2 & 110.0 & 3.0 & 107.9 & 3.0 & 100.8 & 3.2 & 107.9, 96.7 & 3.2 \\
\hline 6 & 104.7 & 1.8 & 104.7 & 1.9 & 104.8 & 2.0 & 102.7 & 1.8 & 94.2 & 2.3 & $102.5,88.7$ & 2.0 \\
\hline 12 & 99.2 & 0.98 & 99.0 & 1.0 & 99.0 & 1.1 & 97.0 & 1.0 & 87.4 & 1.4 & $96.0,81.6$ & 1.1 \\
\hline 24 & 96.3 & 0.75 & 96.0 & 0.83 & 95.5 & 0.80 & 93.4 & 0.77 & 83.4 & 1.0 & $92.0,74.2$ & 0.53 \\
\hline
\end{tabular}

a: The half time of crystallization. 
tals in Bl-90. Compatibility of sPP and sPB at the molten state was observed with with hot-stage microscopy at $200^{\circ} \mathrm{C}$. The blend samples of $\mathrm{Bl}-10, \mathrm{Bl}-25, \mathrm{Bl}-50$, and Bl-75 showed the miscible molten phase. On the other hand, the micro graphs of $\mathrm{Bl}-90$ indicated the texture derived from the two-phase separation. The crystallization from the two-phase separated molten state should induce the complex crystallization process and form the two kinds of crystals of sPP in Bl-90.

Figure 2(A) and Figure 2(B) show relationship between crystallization time $(t)$ and weight fraction of crystallized sPP at time $t, X(t)$, of $\mathrm{Bl}-25$ and $\mathrm{Bl}-90$. Bl-25 showed sigmoid curves with induction periods for the nucleation at the early stage of crystallization as shown in Figure 2(A). Other blend samples, except Bl-90, also showed the similar profiles. By contrast, the crystallization profile of Bl-90 indicated two-step crystallization, as shown in Figure 2(B).

The half time of the crystallization $\left(t_{1 / 2}\right), t$ at $X(\mathrm{t})=0.5$, of the blend samples on the constant cooling rates is summarized in Table 1 . The $t_{1 / 2} \mathrm{~S}$ of $\mathrm{Bl}-10, \mathrm{Bl}-25$, and $\mathrm{Bl}-50$ were almost same. The $t_{1 / 2} \mathrm{~S}$ of $\mathrm{Bl}-75$ were larger than those of the other blend samples.

Supahol investigated kinetics of non-isothermal crystallization of sPP by various macro kinetic models, and found that Ozawa model was suitable to study the crystallization kinetics of sPP [44]. We used this model to study the crystallization kinetics of sPP in the sPP-sPB blend samples. Non-isothermal crystallization behavior

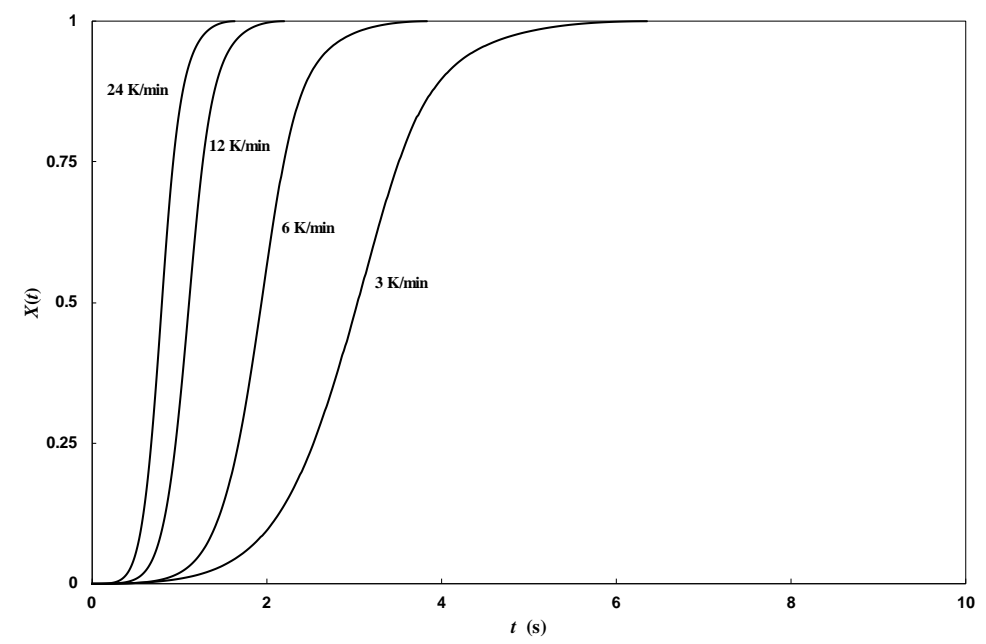

(A)

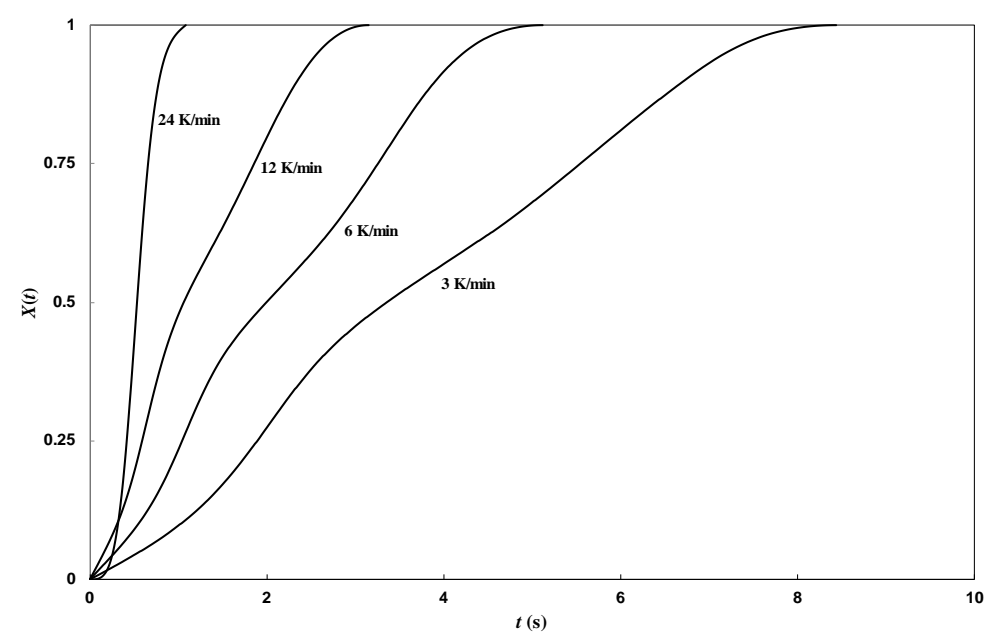

(B)

Figure 2. Relationship between crystallization time $(t)$ and weight fraction of crystallized sPP crystalized at time t, $X(t)$, of (A) Bl-25, and (B) Bl-90 from $180^{\circ} \mathrm{C}$ to $20^{\circ} \mathrm{C}$ at the cooling rate of $3^{\circ} \mathrm{C}, 6^{\circ} \mathrm{C}, 12^{\circ} \mathrm{C}$, or $24^{\circ} \mathrm{C} / \mathrm{min}$. 
on a constant cooling rate $\phi$ of polymers can be analyzed by the following Equation (1), developed by Ozawa [45]:

$$
\ln \{-\ln [1-X(t)]\}=\chi-n \ln |\phi|
$$

where $\chi$ represents the cooling crystallization function and $n$ represents Avrami exponent. The Avrami exponent of sPP in the blend samples was determined by the slope of the plots between $\ln |\phi|$ and $\ln \{-\ln [1-X(\mathrm{t})]\}$ at theconstant temperatures. Figure 3 shows the relationship between $\ln |\phi|$ and $\ln \{-\ln [1-X(\mathrm{t})]\}$ of the blend samples at $100^{\circ} \mathrm{C}$. The Avrami exponents $(n)$ of the neat sPP, Bl-10, Bl-25, and Bl-50 were approximately 2.8 - 2.9. Bl75 showed the large $n$ (4.8). Bl-90 did not showed linearity of the plots. The Avrami exponents $(n)$ and the corresponding correlation $\left(r^{2}\right)$ of the plots at various temperatures of the blend samples are summarized in Table 2. The $n$ values increased with increasing of the temperatures, as previously reported about the crystallization of sPP [44]. The large $n$ values of Bl-75 should be caused by the slow crystallization of sPP in the blend samples. Most of the plots of Bl-90 did not show linearity. The cooling rate strongly affected the two-step crystallization behavior of sPP in Bl-90 from the two-phase separated molten state.

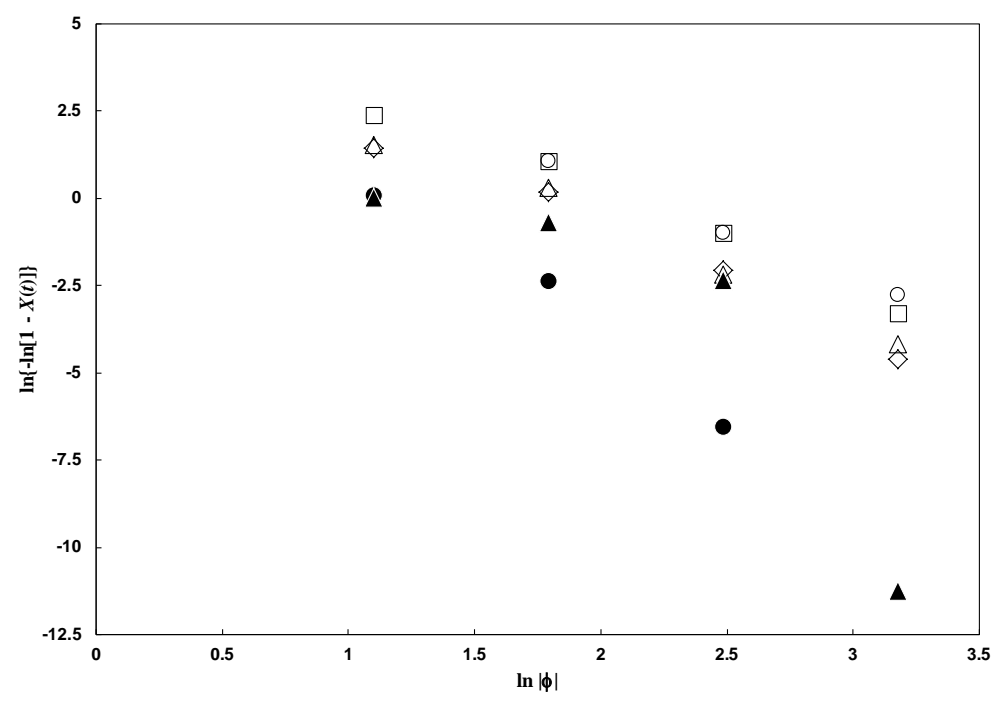

Figure 3. Relationship between $\ln |\phi|$ and $\ln \{-\ln [1-X(t)]\}$ of sPP (०) and sPP-sPB blends, Bl-10 $(\triangle)$, Bl-25 $(\square)$, Bl-50 $(\diamond), \mathrm{Bl}-75(\bullet)$, and Bl-90 $(\boldsymbol{\Delta})$ at $100^{\circ} \mathrm{C}$.

Table 2. Avrami exponent of sPP and sPP-sPB onnon isothermal crystallization determined by Ozawa analysis.

\begin{tabular}{|c|c|c|c|c|c|c|c|c|c|c|c|c|}
\hline \multirow{2}{*}{$\begin{array}{c}T \\
{ }^{\circ} \mathrm{C}\end{array}$} & \multicolumn{2}{|c|}{ sPP } & \multicolumn{2}{|c|}{ Bl-10 } & \multicolumn{2}{|c|}{ Bl-20 } & \multicolumn{2}{|c|}{$\mathrm{Bl}-50$} & \multicolumn{2}{|c|}{$\mathrm{Bl}-75$} & \multicolumn{2}{|c|}{ Bl-90 } \\
\hline & $n$ & $r^{2}$ & $n$ & $r^{2}$ & $n$ & $r^{2}$ & $n$ & $r^{2}$ & $n$ & $r^{2}$ & $n$ & $r^{2}$ \\
\hline 106 & 5.14 & 0.97 & & & & & & & & & & \\
\hline 104 & 3.67 & 0.96 & 4.35 & 0.99 & 4.05 & 0.97 & 4.92 & 0.97 & & & & \\
\hline 102 & 2.82 & 0.96 & 3.51 & 0.99 & 3.20 & 0.97 & 3.67 & 0.98 & & & & \\
\hline 100 & 2.77 & 0.99 & 2.83 & 0.99 & 2.75 & 0.99 & 2.94 & 0.98 & 4.80 & 0.98 & 5.12 & 0.77 \\
\hline 98 & & & 2.32 & 0.99 & 2.38 & 0.99 & 2.57 & 0.99 & 4.66 & 0.99 & 2.43 & 0.89 \\
\hline 96 & & & & & & & & & 3.81 & 0.99 & 1.60 & 0.96 \\
\hline 94 & & & & & & & & & 3.43 & 0.99 & 1.11 & 0.99 \\
\hline 92 & & & & & & & & & & & 0.79 & 0.83 \\
\hline
\end{tabular}

$n$ : Avrami exponent, $r^{2}$ : Corresponding correlation of the plots. 


\subsection{Crystallization Process of Blend Samples for Long Period}

The crystallization process of the blend samples at room temperature was traced by FT-IR spectroscopy to study the structure transformation of SPP and SPB in the blend samples for long period. The FT-IR spectra of sPP, $\mathrm{Bl}-10$, and $\mathrm{Bl}-25$, did not show any time change. The results indicate that the structures of the crystalline, mesophase, and amorphous phase of sPP in the samples should be fixed within a short period approximately 2 min. Figure 4 shows the time-resolved FT-IR spectraofBl-75. The peaks intensity at 811 , and $867 \mathrm{~cm}^{-1}$ derived from the helical structure of sPP in the crystal [46]-[48] increased with increasing the crystallization time within 15 min. Bl-50 also showed the slight increase of the intensity of these peaks during the crystallization within 5 min. An isothermal slow crystallization of sPP at high temperatures showed a similar time change of the FT-IR spectra [49]. The slow crystallization of sPP in Bl-50, and Bl-75 should induce the time change of the intensity of the peaks observed in FT-IR spectroscopy. sPB should disturb the formation of the helical structure in the crystalline phase of sPP during the crystallization from the miscible molten phase of Bl-50 and Bl-75. Figure 5 shows the time-resolved FT-IR spectra of Bl-90. The spectra did not show any time dependence of the profiles of those absorption peaks. The crystal of sPP should be formed independent of sPB from the two-phase molten sample of Bl-90.

The FT-IR spectroscopy detects the helical conformation and the planar zigzag conformation in the amorphous phase and mesophase of sPP. The peak intensity at $1153 \mathrm{~cm}^{-1}$, derived from planar zigzag conformations in

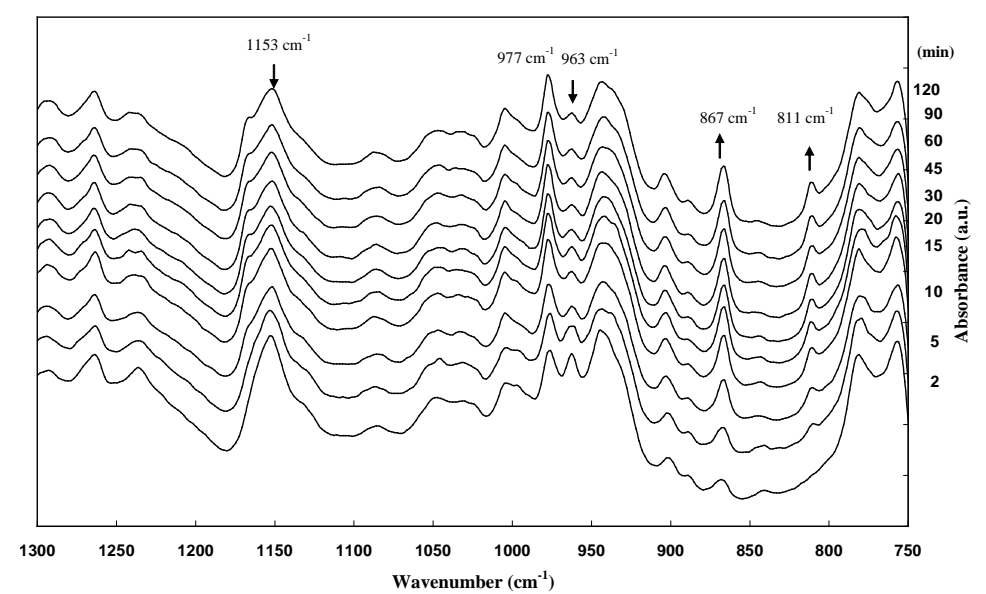

Figure 4. Time-resolved FT-IR spectra of Bl-75 crystallized for 2 (bottom), 5, $10,15,20,30,45,60,90$, and 120 (top) $\min$.

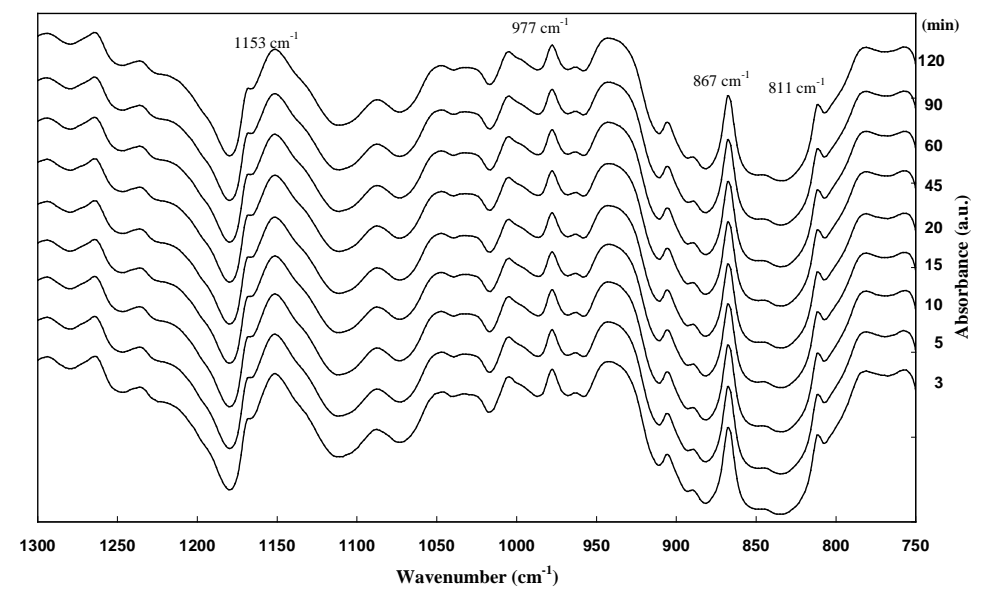

Figure 5. Time-resolved FT-IR spectra of Bl-90 crystallized for 3 (bottom), 5 , $10,15,20,30,45,60,90$, and 120 (top) $\min$. 
the amorphous phase, of the Bl-50 and Bl-75 samples decreased with increasing the crystallization time. The absorption peaks derived from the planar zigzag and the helical conformations in the mesophase are detected at 963 and $977 \mathrm{~cm}^{-1}$, respectively [46]-[48]. Intensity ratio of the peaks at 963 and $977 \mathrm{~cm}^{-1} \mathrm{R}\left(\mathrm{A}_{963} / \mathrm{A}_{977}\right)$ is useful to discuss the conformational change of sPP in the mesophase quantitatively, as previously reported [50]-[52]. Figure 6 shows a relationship between the crystallization time and the $\mathrm{R}\left(\mathrm{A}_{963} / \mathrm{A}_{977}\right)$ of all the samples. $\mathrm{Bl}-50$ and $\mathrm{Bl}-75$ showed decrease of $\mathrm{R}\left(\mathrm{A}_{963} / \mathrm{A}_{977}\right)$ ratio with increasing the crystallization time due to the decrease of the peak intensity at $963 \mathrm{~cm}^{-1}$. By contrast, the $\mathrm{R}\left(\mathrm{A}_{963} / \mathrm{A}_{977}\right)$ ratios of other samples were almost independent of the crystallization time. These results indicate that the transformation of the planar zigzag conformations in the mesophase of sPP slowly occurs in Bl-50 and Bl-75. One explanation for the results is that sPB of these blend samples would permeate in the mesophases of sPP, and would decrease the mobility of the polymer chains in the planar zigzag conformation.

All the crystallized blend samples (crystallization for $120 \mathrm{~min}$ ) showed lower $\mathrm{R}\left(\mathrm{A}_{963} / \mathrm{A}_{977}\right)$ values than that of the neat sPP. The FT-IR spectra cleared that the decrease of the absorbance intensity at $963 \mathrm{~cm}^{-1}\left(\mathrm{~A}_{963}\right)$, derived from planar zigzag conformations of the mesophase phase, caused the decrease of the $R\left(A_{963} / A_{977}\right)$ values in the blend samples. $\mathrm{Bl}-75$ showed the lowest $\mathrm{R}\left(\mathrm{A}_{963} / \mathrm{A}_{977}\right)$ value among the blend samples. These results indicate that sPB prevents the formation of the planar zigzag conformations in the mesophase formed on the cooling process from the miscible molten state. The $\mathrm{R}\left(\mathrm{A}_{963} / \mathrm{A}_{977}\right)$ value of $\mathrm{Bl}-90$ was larger than that of $\mathrm{Bl}-75$, due to the isolated crystallization of sPP and sPB from the phase-separated molten state.

Slow crystallization of sPB in Bl-90 makes it possible to trace the crystallization process by WAXD. Figure 7 shows the time evolution of the WAXD profiles of Bl-90 and sPB. It took about 4 weeks to almost complete the crystallization of SPB due to its low crystallization rate [40]. By contrast, the crystallization of SPB in Bl-90 completed within 1 week. In the same way, the time evolution of the FT-IR spectra of Bl-90 showed rapid increase of the peak intensity derived from the crystalline structure of sPB at 993 and $1209 \mathrm{~cm}^{-1}$ for 1 week crystallization, as shown in Figure 8. These results indicate that addition of $10 \mathrm{wt} \%$ of sPP to sPB accelerates the crystallization of sPB. sPP crystals in Bl-90 would play a role of a nucleating agent for sPB.

\subsection{Crystalline Structure of Blend Samples}

Figure 9 shows the WAXD patterns of sPP, Bl-10, Bl-25, Bl-50, and Bl-75 crystallized at room temperature for 4 weeks. The diffraction angles of the WAXD profiles are summarized in Table 3. sPP and the blend samples $\mathrm{Bl}-10, \mathrm{Bl}-25, \mathrm{Bl}-50$, and $\mathrm{Bl}-75$ showed the diffraction peaks at $2 \theta=12.1^{\circ}, 15.8^{\circ}$, and $20.5^{\circ}$ derived from (200), $(010)$ or $(020)$ and $(220,121)$ reflection planes of the sPP crystal, respectively. Bl-75 also showed a weak diffraction peak derived from the SPB crystal at $2 \theta=10.5^{\circ}$. Bl-90 showed the diffraction peaks derived from not

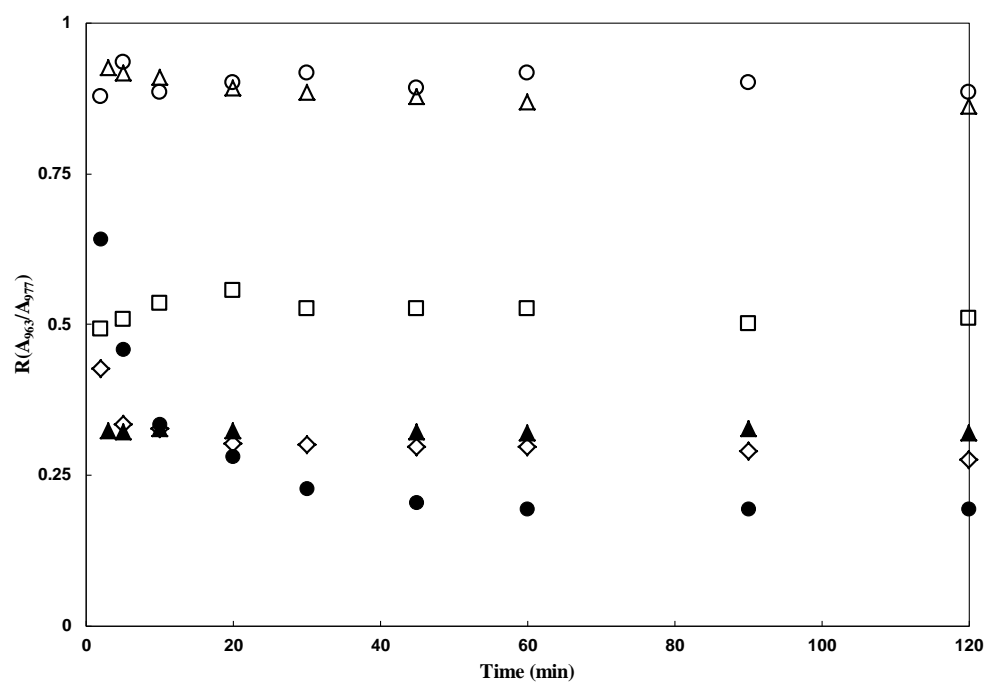

Figure 6. Relationship between crystallization time and intensity ratio of the absorbance at 963 and $977 \mathrm{~cm}^{-1}, \mathrm{R}\left(\mathrm{A}_{963} / \mathrm{A}_{977}\right)$ of sPP $(\circ)$ and sPP-sPB blends, $\mathrm{Bl}-10(\triangle), \mathrm{Bl}-25(\square), \mathrm{Bl}-50(\diamond), \mathrm{Bl}-75(\bullet)$, and Bl-90 $(\boldsymbol{\Delta})$. 


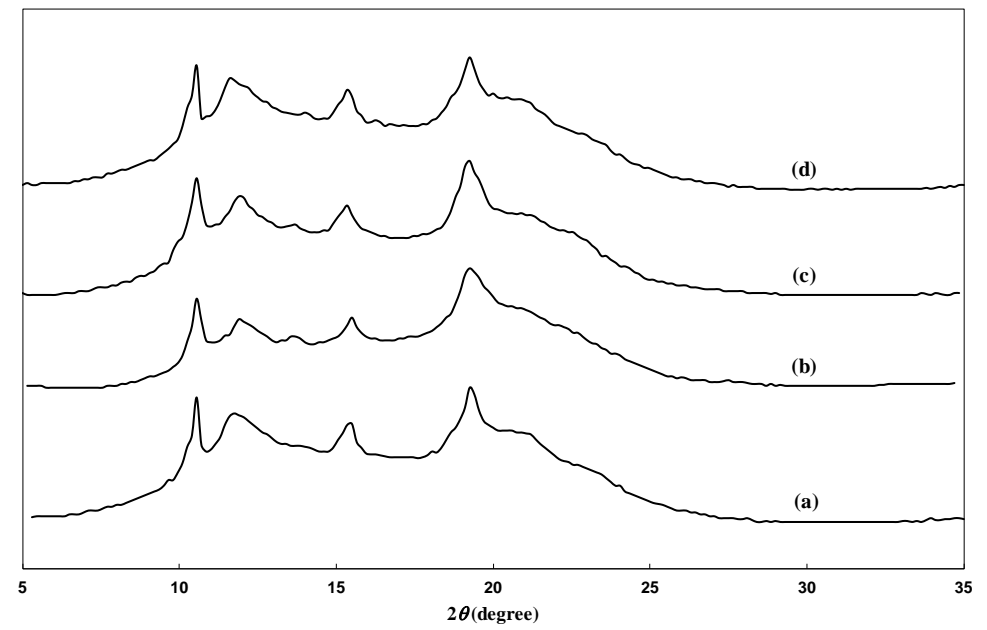

(A)

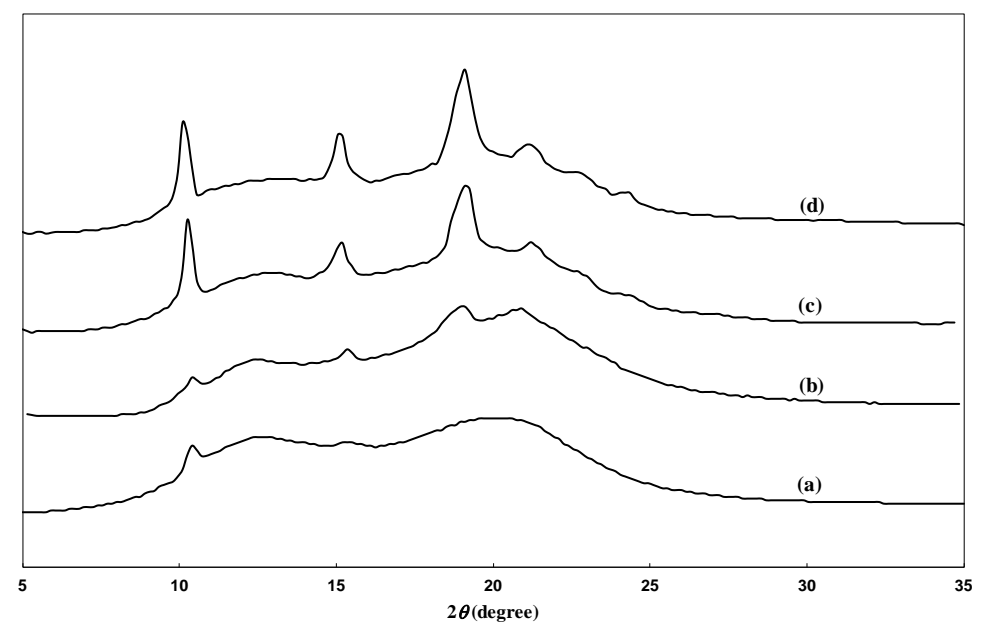

(B)

Figure 7. WAXD profiles of (A) Bl-90 and (B) sPB crystallized for (a) 1, (b) 2, (c) 3, and (d) 4 week.

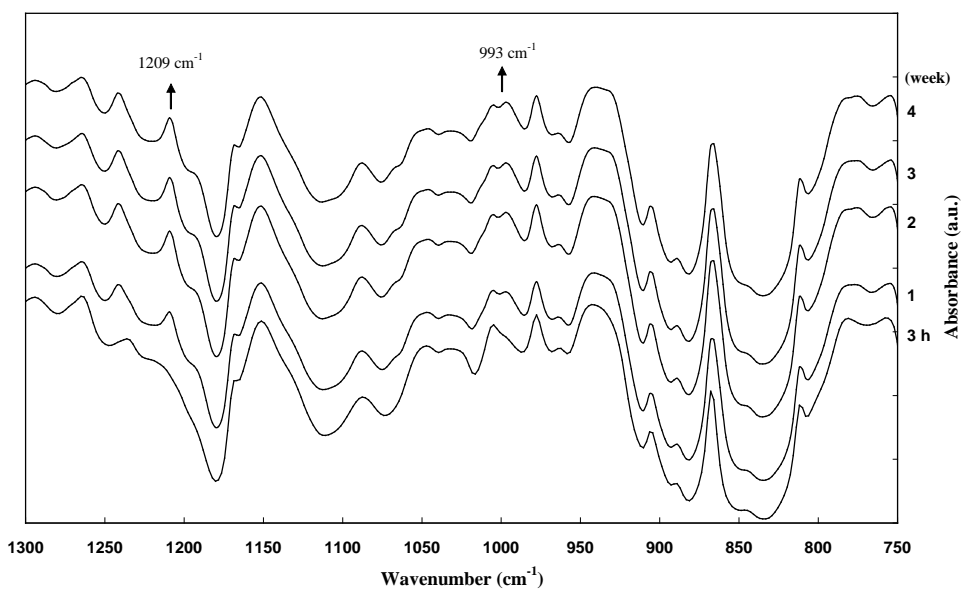

Figure 8. FT-IR spectra of Bl-90 crystallized for 3 h (bottom) 1, 2, 3, and 4 week (top). 


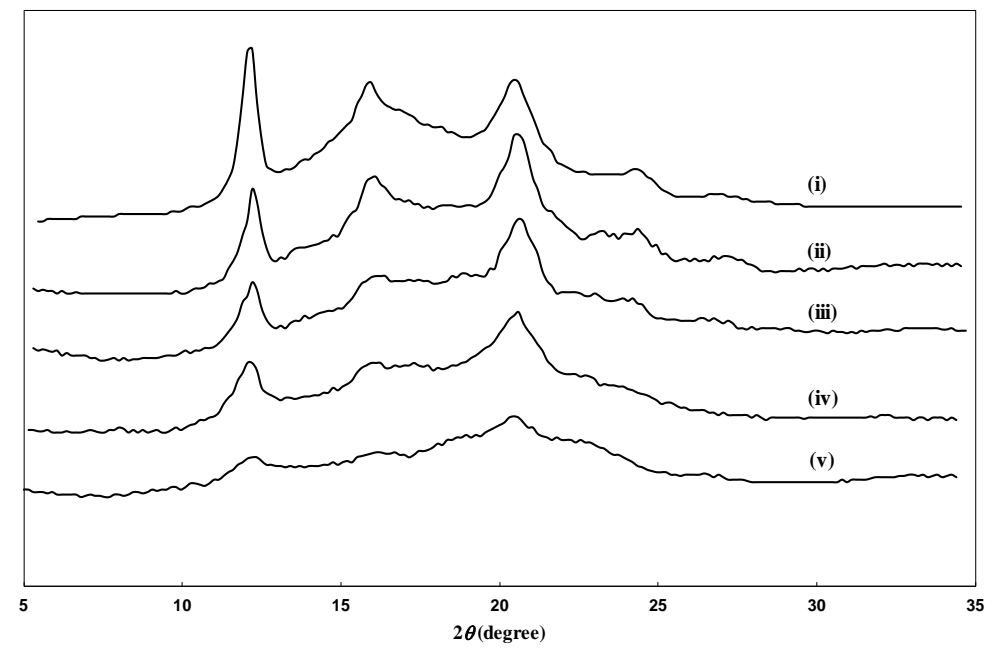

Figure 9. WAXD patterns of sPP and sPP-sPB blends crystallized at room temperature for 4 weeks, (i) sPP, (ii) $\mathrm{Bl}-10$, (iii) $\mathrm{Bl}-25$, (iv) $\mathrm{Bl}-50$, and (v) Bl-75.

Table 3. Diffraction angles and thermal properties of sPP, sPP-sPB blends, and sPB.

\begin{tabular}{|c|c|c|c|c|c|c|c|c|c|c|c|c|}
\hline \multirow{3}{*}{ Sample } & \multirow{3}{*}{$\begin{array}{l}\text { sPB } \\
\text { wt\% }\end{array}$} & \multicolumn{4}{|c|}{ sPP } & \multirow{2}{*}{\multicolumn{3}{|c|}{$\begin{array}{c}\text { sPB } \\
2 \theta\left(^{\circ}\right)\end{array}$}} & \multirow{3}{*}{$\begin{array}{c}T_{\mathrm{mPP}}{ }^{\mathrm{a}} \\
{ }^{\circ} \mathrm{C}\end{array}$} & \multirow{3}{*}{$\begin{array}{c}\square H_{\mathrm{mPP}}{ }^{\mathrm{b}} \\
\mathrm{J} / \mathrm{g}\end{array}$} & \multirow{3}{*}{$\begin{array}{c}T_{\mathrm{mPB}}{ }^{\mathrm{a}} \\
{ }^{\circ} \mathrm{C}\end{array}$} & \multirow{3}{*}{$\begin{array}{c}\square H_{\mathrm{mPB}}{ }^{\mathrm{b}} \\
\mathrm{J} / \mathrm{g}\end{array}$} \\
\hline & & \multirow[b]{2}{*}{ (200) } & \multicolumn{2}{|l|}{$2 \theta\left(^{\circ}\right)$} & \multirow[b]{2}{*}{$I_{200} / I_{010}{ }^{c}$} & & & & & & & \\
\hline & & & (010) & $\begin{array}{l}(200) \\
(122)\end{array}$ & & (200) & (110) & (210) & & & & \\
\hline sPP & 0 & 12.3 & 15.9 & 20.5 & 1.41 & & & & 147.7 & 42.3 & & \\
\hline Bl-10 & 10 & 12.3 & 15.9 & 20.5 & 1.12 & & & & 147.0 & 41.2 & & \\
\hline Bl-25 & 25 & 12.3 & 15.9 & 20.5 & 1.05 & & & & 147.0 & 40.8 & & \\
\hline Bl-50 & 50 & 12.3 & 15.9 & 20.5 & 1.03 & & & & 146.8 & 40.4 & & \\
\hline Bl-75 & 75 & 12.3 & 15.9 & 20.5 & 0.93 & 10.5 & & & 142.0 & 30.5 & 37.9 & 4.8 \\
\hline Bl-90 & 90 & 11.9 & & & & 10.5 & 15.3 & 19.1 & 144.5 & 32.8 & 39.3 & 10.4 \\
\hline sPB & 100 & & & & & 10.4 & 15.2 & 19.0 & & & 44.7 & 9.6 \\
\hline
\end{tabular}

a: Melting temperature derived from sPP $\left(T_{\mathrm{mPP}}\right)$ or sPB $\left(T_{\mathrm{mPB}}\right)$, b: Heat of fusion derived from sPP $\left(\Delta H_{\mathrm{mPP}}\right)$ or sPB $\left(\Delta H_{\mathrm{mPB}}\right)$ determined by $\mathrm{DSC}$, c: Intensity ratio of the diffraction peaks derived from (200) and (010) planes of sPP crystal.

only the sPB crystal at around $2 \theta=10.5^{\circ}, 15.3^{\circ}$, and $19.1^{\circ}$ but a weak peak derived from the (200) planes of sPP at $2 \theta=11.9^{\circ}$, as shown in Figure 7(A). The diffraction angles of sPB in Bl-90 were almost same to those of sPB derived from the (200), (110), and (210) planes, respectively, as shown in Figure 7(B).

Figure 10 illustrates the DSC melting curves of the blend samples, which were crystallized at room temperature for 4 weeks, on the heating process form room temperature to $200^{\circ} \mathrm{C}$ at a heating rate of $10^{\circ} \mathrm{C} / \mathrm{min}$. The data are summarized Table $3 . \mathrm{Bl}-10, \mathrm{Bl}-25$, and $\mathrm{Bl}-50$ showed a melting peak at around $147^{\circ} \mathrm{C}$ derived from melting of the sPP crystal. The melting temperature $\left(T_{\mathrm{mPP}}\right)$ and heat of fusion $\left(\Delta H_{\mathrm{mPP}}\right)$ of sPP in the bled samples showed only a slight decrease with increasing the sPB content. The DSC melting curves of $\mathrm{Bl}-75$ and $\mathrm{Bl}-90$ showed two melting peaks at around $38^{\circ} \mathrm{C}-40^{\circ} \mathrm{C}$ and $142^{\circ} \mathrm{C}-147^{\circ} \mathrm{C}$. The lower melting peak is derived from the melting of sPB crystal. The $T_{\mathrm{mPP}}$ and $\Delta H_{\mathrm{mPP}}$ values of sPP in $\mathrm{Bl}-75$ were the lowest among the blend samples. This result agrees with the WAXD profiles, that Bl-75 shows the lowest peak intensity, as shown in Figure 9. The melting temperature of $\mathrm{sPB}\left(T_{\mathrm{mPB}}\right)$ in the blend samples, detected in $\mathrm{Bl}-75, \mathrm{Bl}-90$, and sPB, increased with increasing of the sPB content. The increase of occupied volume of sPB in the blend should promote the formation of the sPB crystals with thick lamellae. 


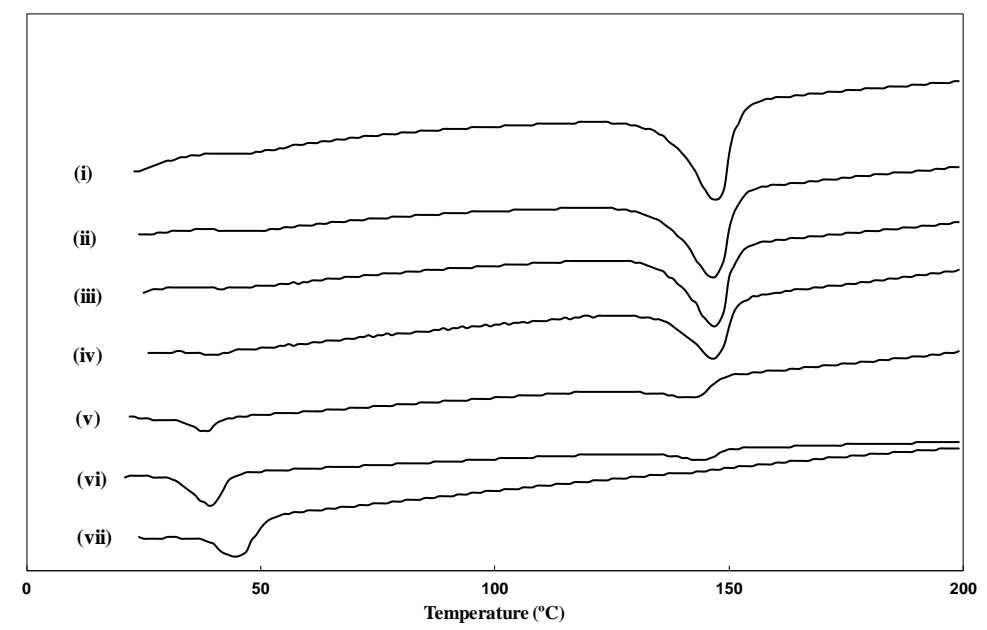

Figure 10. DSC melting curves of sPP and sPP-sPB blends crystallized at room temperature for 4 weeks, (i) sPP, (ii) Bl-10, (iii) Bl-25, (iv) Bl-50, (v) $\mathrm{Bl}-75$, (vi) Bl-90, and (vii) sPB.

\section{Conclusions}

The crystallization and crystalline structure of the sPP-sPB blends were successively investigated with the WAXD, DSC, and FT-IR measurements. The WAXD patterns and the DSC profiles showed that the large amount of sPP in the blend samples in $\mathrm{Bl}-10$, and $\mathrm{Bl}-25$ prevented the crystallization of sPB. The crystallization behavior and thermal properties of sPP in those blend samples were not affected by sPB. The $T_{\mathrm{c}} \mathrm{S}$ of sPP in Bl-50, $\mathrm{Bl}-75$, and Bl-90 were lower than that of the neat sPP. The $T_{\mathrm{m}}$ and $\Delta H_{\mathrm{m}}$ of sPP in Bl-75 were the lowest among the blend samples. A part of sPP in $\mathrm{Bl}-90$ formed the isolate crystals, and induced the heterogeneous two-step crystallization. The portion of planar zigzag conformations in the mesophase and amorphous phase of sPP in $\mathrm{Bl}-50$, and $\mathrm{Bl}-75$ gradually decreased with increasing the crystallization time. The ratio of the planar zigzag conformation to the helical $\left(\mathrm{t}_{2} \mathrm{~g}_{2}\right)_{2}$ conformation of sPP in the mesophases decreased with increasing of the sPB content in the blend samples, except Bl-90. sPB could be crystallized in Bl-75 and Bl-90.

More detailed studies, especially transmission electron microscopic study and solid NMR spectroscopy, of the crystalline structure of the blend samples are now being carried out, and the results will be reported elsewhere.

\section{References}

[1] Brintzinger, H.H., Fischer, D., Mülhaupt, R., Rieger, B. and Waymouth, R.M. (1995) Stereospecific Olefin Polymerization with Chiral Metallocene Catalysts. Angewandte Chemie International Edition, 34, 1143-1170.

http://onlinelibrary.wiley.com/doi/10.1002/anie.199511431

http://dx.doi.org/10.1002/anie.199511431

[2] Ewen, J.A., Loria, R.L., Razavi, A. and Ferrara, J.D. (1988) Syndiospecific Propylene Polymerizations with Group IVB Metallocenes. Journal of the America Chemcal Society, 110, 6255-6256. http://pubs.acs.org/doi/abs/10.1021/ja00226a056

[3] Asanuma, T., Nishimori, Y., Ito, M., Uchikawa, N. and Shiomura, T. (1991) Preparation of Syndiotactic Polyolefins by Using Metallocene Catalysts. Polymer Bulletin, 25, 567-570. http://link.springer.com/article/10.1007\%2FBF00293515 http://dx.doi.org/10.1007/BF00293515

[4] Lotz, B., Lovinger, A.J. and Cais, R.E. (1988) Crystal Structure and Morphology of Syndiotactic Polypropylene Single Crystals. Macromolecules, 21, 2375-2387. http://dx.doi.org/10.1021/ma00186a013

[5] Lovinger, A.J., Lotz, B. and Davis, D.D. (1990) Interchain Packing and Unit Cell of Syndiotactic Polypropylene. Polymer, 31, 2253-2259.

http://www.sciencedirect.com/science/article/pii/003238619090310U http://dx.doi.org/10.1016/0032-3861(90)90310-U

[6] Lovinger, A.J., Davis, D.D. and Lotz, B. (1991) Temperature Dependence of Structure and Morphology of Syndiotactic Polypropylene and Epitaxial Relationships with Isotactic Polypropylene, Macromolecules, 24, 552-560. 
http://pubs.acs.org/doi/abs/10.1021/ma00002a033

http://dx.doi.org/10.1021/ma00002a033

[7] De Rosa, C. and Corradini, P. (1993) Crystal Structure of Syndiotactic Polypropylene. Macromolecules, 26, 5711-5718. http://pubs.acs.org/doi/abs/10.1021/ma00073a028 http://dx.doi.org/10.1021/ma00073a028

[8] Chatani, Y., Maruyama, H., Noguchi, K., Asanuma, T. and Shiomura, T. (1990) Crystal Structure of the Planar Zigzag form of Syndiotactic Polypropylene. Journal of Polymer Science Part C: Polymer Letters, 28, 393-398.

http://onlinelibrary.wiley.com/doi/10.1002/pol.1990.140281301 http://dx.doi.org/10.1002/pol.1990.140281301

[9] Chatani, Y., Maruyama, H., Asanuma, T. and Shiomura, T. (1991) Structure of a New Crystalline Phase of Syndiotactic Polypropylene. Journal of Polymer Science Part B: Polymer Physics, 29, 1649-1652.

http://onlinelibrary.wiley.com/doi/10.1002/polb.1991.090291310 http://dx.doi.org/10.1002/polb.1991.090291310

[10] De Rosa, C., Auriemma, F. and Vinti, V. (1997) Disordered Polymorphic Modifications of Form I of Syndiotactic Polypropylene. Macromolecules, 30, 4137-4146. http://pubs.acs.org/doi/abs/10.1021/ma961691f http://dx.doi.org/10.1021/ma961691f

[11] De Rosa, C., Auriemma, F. and Vinti, V. (1998) On the Form II of Syndiotactic Polypropylene. Macromolecules, 31, 7430-7435. http://pubs.acs.org/doi/abs/10.1021/ma980789m http://dx.doi.org/10.1021/ma980789m

[12] Zhang, J., Yang, D., Thierry, A.J., Wittmann, C. and Lotz, B. (2001) Isochiral Form II of Syndiotactic Polypropylene Produced by Epitaxial Crystallization. Macromolecules, 34, 6261-6267. http://pubs.acs.org/doi/abs/10.1021/ma010758i

[13] Rastogi, S., La Camera, D., van der Burgt, F., Terry, A.E. and Cheng, S.Z.D. (2001) Polymorphism in Syndiotactic Polypropylene: Thermodynamic Stable Regions for Form I and Form II in Pressure-Temperature Phase Diagram. Macromolecules, 34, 7730-7736. http://pubs.acs.org/doi/abs/10.1021/ma0109119 http://dx.doi.org/10.1021/ma0109119

[14] Guadagno, L., D’Aniello, C., Naddeo, C., Vittoria, V. and Meille, S.V. (2002) Elasticity of the Oriented Mesomorphic Form of Syndiotactic Polypropylene. Macromolecules, 35, 3921-3927. http://pubs.acs.org/doi/abs/10.1021/ma011825b http://dx.doi.org/10.1021/ma011825b

[15] De Rosa, C., Venditto, V., Guerra, G., Pirozzi, B. and Corradini, P. (1991) Polymorphism and Chain Conformations in the Crystalline Forms of Syndiotactic Poly(1-Butene). Macromolecules, 24, 5645-5650.

http://pubs.acs.org/doi/abs/10.1021/ma00020a025 http://dx.doi.org/10.1021/ma00020a025

[16] De Rosa, C., Venditto, V., Guerra, G. and Corradini, P. (1992) Crystal Structure of the Form I of Syndiotactic Poly(1-Butene). Die Makromolekulare Chemie, 193, 1351-1358. http://dx.doi.org/10.1002/macp.1992.021930611 http://onlinelibrary.wiley.com/doi/10.1002/macp.1992.021930611

[17] Zhang, B., Yang, D., De Rosa, C., Yan, S. and Petermann, J. (2001) Single Crystal Structure of Form I Syndiotactic Poly(Butene-1), Macromolecules, 34, 5221-5223. http://pubs.acs.org/doi/abs/10.1021/ma010036r http://dx.doi.org/10.1021/ma010036r

[18] Galimberti, M., Balbontin, G., Camurati, I. and Paganetto, G. (1994) Crystalline Syndiotactic Poly(1-Pentene). Macromolecular Rapid Communications, 15, 633-638. http://dx.doi.org/10.1002/marc.1994.030150803 http://onlinelibrary.wiley.com/doi/10.1002/marc.1994.030150803

[19] De Rosa, C., Venditto, V., Guerra, G. and Corradini, P. (1992) Chain Conformation and Unit Cell in the Crystalline Phase of Syndiotactic Poly(4-Methyl-1-Pentene). Macromolecules, 25, 6938-6942.

http://pubs.acs.org/doi/abs/10.1021/ma00051a034 http://dx.doi.org/10.1021/ma00051a034

[20] De Rosa, C., Venditto, V., Guerra, G. and Corradini, P. (1995) Crystal Structure of Syndiotactic Poly(4-Methyl-1-Pentene). Polymer, 36, 3619-3624. http://www.sciencedirect.com/science/article/pii/003238619593762B http://dx.doi.org/10.1016/0032-3861(95)93762-B

[21] Uozumi, T. and Soga, K. (1992) Copolymerization of Olefins with Kaminsky-Sinn-Type Catalysts. Die Makromolekulare Chemie, 193, 823-831. http://onlinelibrary.wiley.com/doi/10.1002/macp.1992.021930401 http://dx.doi.org/10.1002/macp.1992.021930401

[22] Jüngling, S., Mülhaupt, R., Fischer, D. and Langhauser, F. (1995) Modified Syndiotactic Polypropene: Poly(Propeneco-Octene) and Blends with Atactic Oligopropene. Die Angewandte Makromolekulare Chemie, 229, 93-112. http://onlinelibrary.wiley.com/doi/10.1002/apmc.1995.052290106 http://dx.doi.org/10.1002/apmc.1995.052290106 
[23] Naga, N., Mizunuma, K., Sadatoshi, H. and Kakugo, M.(1997) Properties and Crystalline Structures of Syndiotactic Poly(Propylene-co-1-Butene). Macromolecules, 30, 2197-2200. http://pubs.acs.org/doi/abs/10.1021/ma961438f http://dx.doi.org/10.1021/ma961438f

[24] Thomann, R., Kressler, J. and Mülhaupt, R. (1997) Single Crystals of Syndiotactic Poly[Propene-co-(1-Octene)] and Syndiotactic Polypropene Crystallized in Bulk. Macromolecular Chemistry and Physics, 198, 1271-1279. http://onlinelibrary.wiley.com/doi/10.1002/macp.1997.021980428 http://dx.doi.org/10.1002/macp.1997.021980428

[25] De Rosa, C., Auriemma, F., Vinti, V., Grassi, A. and Galimberti, M. (1998) Polymorphism of Syndiotactic Polypropylene in Copolymers of Propylene with Ethylene and 1-Butene. Polymer, 39, 6219-6226. http://www.sciencedirect.com/science/article/pii/S0032386197101744 http://dx.doi.org/10.1016/S0032-3861(97)10174-4

[26] De Rosa, C., Talarico, G., Caporaso, L., Auriemma, F., Galimberti, M. and Fusco, O. (1998) Structural Characterization of Syndiotactic Copolymers of Propene with 1-Butene. Macromolecules, 31, 9109-9115. http://pubs.acs.org/doi/abs/10.1021/ma981020c http://dx.doi.org/10.1021/ma981020c

[27] Naga, N., Mizunuma, K., Sadatoshi, H. and Kakugo, M. (2000) Isothermal Crystallization of Syndiotactic Poly(Propylene-co-Olefin)s. Polymer, 41, 203-209. http://www.sciencedirect.com/science/article/pii/S0032386199001639 http://dx.doi.org/10.1016/S0032-3861(99)00163-9

[28] De Rosa, C., Auriemma, F., Fanelli, E., Talarico, G. and Capitani, D. (2003) Structure of Copolymers of Syndiotactic Polypropylene with Ethylene. Macomolecules, 36, 1850-1864. http://pubs.acs.org/doi/abs/10.1021/ma020981v

[29] Radulescu, A., Mathers, R.T., Coates, G.W., Richter, D. and Fetters, L.J. (2004) A SANS Study of the Self-Assembly in Solution of Syndiotactic Polypropylene Homopolymers, Syndiotactic Polypropylene-Block-Poly(Ethylene-co-Propylene) Diblock Copolymers and an Alternating Atactic-Isotactic Multisegment Polypropylene. Macromolecules, 37, 6962-6971. http://pubs.acs.org/doi/abs/10.1021/ma049426e http://dx.doi.org/10.1021/ma049426e

[30] Arranz-Andrés, J., Guevara, J.L., Velilla, T., Quijada, R., Benavente, R., Pérez, E. and Cerrada, M.L. (2005) Syndiotactic Polypropylene and Its Copolymers with Alpha-Olefins. Effect of Composition and Length of Comonomer. Polymer, 46, 12287-12297. http://www.sciencedirect.com/science/article/pii/S0032386105015430 http://dx.doi.org/10.1016/j.polymer.2005.10.078

[31] De Rosa, C. and Auriemma, F. (2006) Mechanical Properties of Syndiotactic Propylene-Ethylene Copolymers. Macromolecules, 39, 249-256. http://pubs.acs.org/doi/abs/10.1021/ma051228f http://dx.doi.org/10.1021/ma051228f

[32] De Rosa, C. and Auriemma, F. (2006) Structure of Syndiotactic Propylene-Ethylene Copolymers: Effect of the Presence of Ethylene Units on the Structural Transitions during Plastic Deformation and Annealing of Syndiotactic Polypropylene. Polymer, 47, 2179-2188. http://www.sciencedirect.com/science/article/pii/S0032386106000528 http://dx.doi.org/10.1016/j.polymer.2006.01.055

[33] Allegra, S.V. and Porzio, W. (1999) Isomorphous Polymer Pairs. In: Brandrup, J., Immergut, E.H. and Grulke, E.A., Eds., Polymer Handbook, 4th Edition, Wiley \& Sons, Inc., New York, 399-407.

[34] Gorrasi, G., Vittoria, V. and Longo, P. (2001) Transport and Mechanical Properties of iPP-sPP Fibers. Journal of Applied Polymer Science, 80, 539-545. http://dx.doi.org/10.1002/1097-4628(20010425)80:4<539::AID-APP1128>3.0.CO;2-3 http://onlinelibrary.wiley.com/doi/10.1002/1097-4628(20010425)80:4\%3C539::AID-APP1128\%3E3.0.CO;2-3

[35] Thomann, R., Kressler, J., Setz, S., Wang, C. and Mülhaupt, R. (1996) Morphology and Phase Behavior of Blends of Syndiotactic and Isotactic Polypropylene: 1. X-Ray Scattering, Light Microscopy, Atomic Force Microscopy and Scanning Electron Microscopy. Polymer, 37, 2627-2634. http://www.sciencedirect.com/science/article/pii/003238619687621X http://dx.doi.org/10.1016/0032-3861(96)87621-X

[36] Thomann, R., Kressler, J., Rudolf, B. and Mülhaupt, R. (1996) Morphology and Phase Behavior of Blends of Syndiotactic and Isotactic Polypropylene: 2. Differential Scanning Calorimetry, Light Transmission Measurements and PVT Measurements. Polymer, 37, 2635-2640. http://www.sciencedirect.com/science/article/pii/0032386196876221 http://dx.doi.org/10.1016/0032-3861(96)87622-1

[37] Wang, Z.G., Phillips, R.A. and Hsiao, B.S. (2001) Morphology Development during Isothermal Crystallization. II. Isotactic and Syndiotactic Polypropylene Blends. Journal of Polymer Science Part B: Polymer Physics, 39, 1876-1888. http://onlinelibrary.wiley.com/doi/10.1002/polb.1162 http://dx.doi.org/10.1002/polb.1162 
[38] Zhang, X., Zhao, Y., Wang, Z., Zheng, C., Dong, X., Su, Z., Sun, P., Wang, D., Han, C.C. and Xu, D. (2005) Morphology and Mechanical Behavior of Isotactic Polypropylene (iPP)/Syndiotactic Polypropylene (sPP) Blends and Fibers. Polymer, 46, 5956-5965. http://www.sciencedirect.com/science/article/pii/S0032386105005641 http://dx.doi.org/10.1016/j.polymer.2005.05.004

[39] Loos, J., Bonnet, M. and Petermann, J. (2000) Morphologies and Mechanical Properties of Syndiotactic Polypropylene (sPP)/Polyethylene (PE) Blends. Polymer, 41, 351-356.

http://www.sciencedirect.com/science/article/pii/S0032386199000920 http://dx.doi.org/10.1016/S0032-3861(99)00092-0

[40] Marquardt, J., Thomann, R., Thomann, Y., Heinmann, J. and Mülhaupt, R. (2001) Miscibility of Branched Ethene Homopolymers with Iso- and Syndiotactic Polypropenes. Macromolecules, 34, 8669-8674. http://pubs.acs.org/doi/abs/10.1021/ma010766z http://dx.doi.org/10.1021/ma010766z

[41] Turner Jones, A. (1966) Cocrystallization in Copolymers of $\alpha$-Olefins II-Butene-1 Copolymers and Polybutene Type II/I Crystal Phase Transition. Polymer, 7, 23-59. http://www.sciencedirect.com/science/article/pii/S0032386166800150 http://dx.doi.org/10.1016/S0032-3861(66)80015-0

[42] Hewett, W.A. and Weir, F.E. (1963) Dynamic Properties of Homo- and Copolymers of 4-Methyl-1-Pentene. Journal of Polymer Science Part A: General Papers, 1, 1239-1244. http://onlinelibrary.wiley.com/doi/10.1002/pol.1963.100010414 http://dx.doi.org/10.1002/pol.1963.100010414

[43] Gohil, R.M. and Petermann, J. (1980) Mixed Crystals in Polymer Blends: Polypropylene-Polybutene-1 System. Journal of Macromolecular Science, Part B: Physics, 18, 217-232. http://www.tandfonline.com/doi/abs/10.1080/00222348008241379?journalCode=lmsb20\#.VAfp6pUcR9M http://dx.doi.org/10.1080/00222348008241379

[44] Supaphol, P. (2000) Nonisothermal Bulk Crystallization and Subsequent Melting Behavior of Syndiotactic Polypropylenes: Crystallization from the Melt State. Journal of Appllied Polymer Science, 78, 338-354. http://dx.doi.org/10.1002/1097-4628(20001010)78:2<338::AID-APP140>3.0.CO;2-Y http://onlinelibrary.wiley.com/doi/10.1002/1097-4628(20001010)78:2\%3C338::AID-APP140\%3E3.0.CO;2-Y

[45] Ozawa, T. (1971) Kinetics of Non-Isothermal Crystallization. Polymer, 12, 150-158. http://www.sciencedirect.com/science/article/pii/0032386171900413 http://dx.doi.org/10.1016/0032-3861(71)90041-3

[46] Sevengney, M.S., Parthasarthy, G., Kannan, R.M., Thurman, D.W. and Fernandez-Ballester, L. (2003) DeformationInduced Morphology Changes and Orientation Behavior in Syndiotactic Polypropylene. Macromolecules, 36, 64726483. http://pubs.acs.org/doi/abs/10.1021/ma025774\%2B http://dx.doi.org/10.1021/ma025774+

[47] Sevengney, M.S., Kannan, R.M., Siedle, A.R., Naik, R. and Naik, V.M. (2006) Vibrational Spectroscopic Investigation of Stereoregularity Effects on Syndiotactic Polypropylene Structure and Morphology. Vibration Spectroscopy, 40, 246256. http://www.sciencedirect.com/science/article/pii/S0924203105001396

[48] Sevengney, M.S., Kannan, R.M., Siedle, A.R. and Percha, P.A. (2005) FTIR Spectroscopic Investigation of Thermal Effects in Semi-Syndiotactic Polypropylene. Journal Polymer Science Part B: Polymer Physics, 43, 439-461. http://onlinelibrary.wiley.com/doi/10.1002/polb.20334 http://dx.doi.org/10.1002/polb.20334

[49] Zheng, K., Liu, R., Chang, H., Shen, D. and Huang, Y. (2009) In Situ FTIR Spectroscopic Study of the Conformational Change of Syndiotactic Polypropylene during the Isothermal Crystallization. Polymer, 50, 5782-5786. http://www.sciencedirect.com/science/article/pii/S0032386109008829 http://dx.doi.org/10.1016/j.polymer.2009.10.017

[50] Guadagno, L., D’Aniello, C., Naddeo, C. and Vittoria, V. (2000) Polymorphism of Oriented Syndiotactic Polypropylene. Macromolecules, 33, 6023-6030. http://pubs.acs.org/doi/abs/10.1021/ma0005973 http://dx.doi.org/10.1021/ma0005973

[51] Guadagno, L., D’Aniello, C., Naddeo, C. and Vittoria, V. (2001) Structure and Physical Properties of Syndiotactic Polypropylene Oriented from Different Polymorphs. Macromolecules, 34, 2512-2521. http://pubs.acs.org/doi/abs/10.1021/ma0019398 http://dx.doi.org/10.1021/ma0019398

[52] De Rosa, C., de Ballesteros, O.R., Santoro, M. and Auriemma, F. (2003) Influence of the Quenching Temperature on the Crystallization of the Trans-Planar Mesomorphic Form of Syndiotactic Polypropylene. Polymer, 44, 6267-6272. http://www.sciencedirect.com/science/journal/00323861/44/20 http://dx.doi.org/10.1016/S0032-3861(03)00569-X 
Scientific Research Publishing (SCIRP) is one of the largest Open Access journal publishers. It is currently publishing more than 200 open access, online, peer-reviewed journals covering a wide range of academic disciplines. SCIRP serves the worldwide academic communities and contributes to the progress and application of science with its publication.

Other selected journals from SCIRP are listed as below. Submit your manuscript to us via either submit@scirp.org or Online Submission Portal.
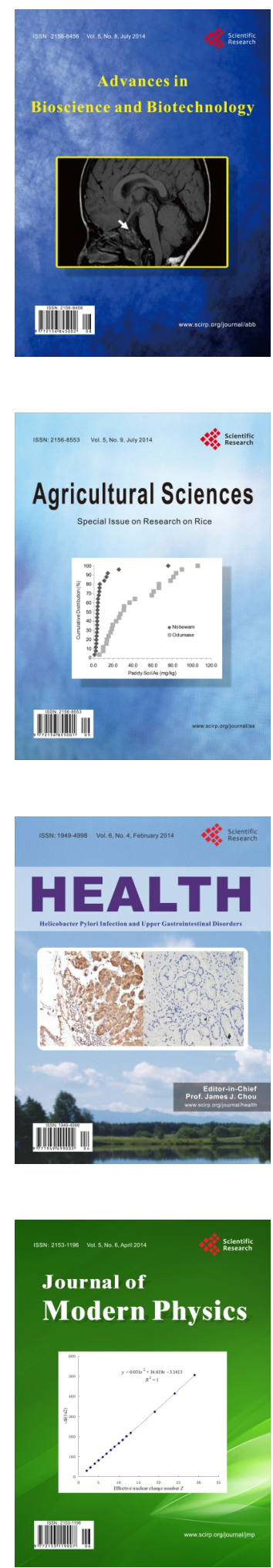
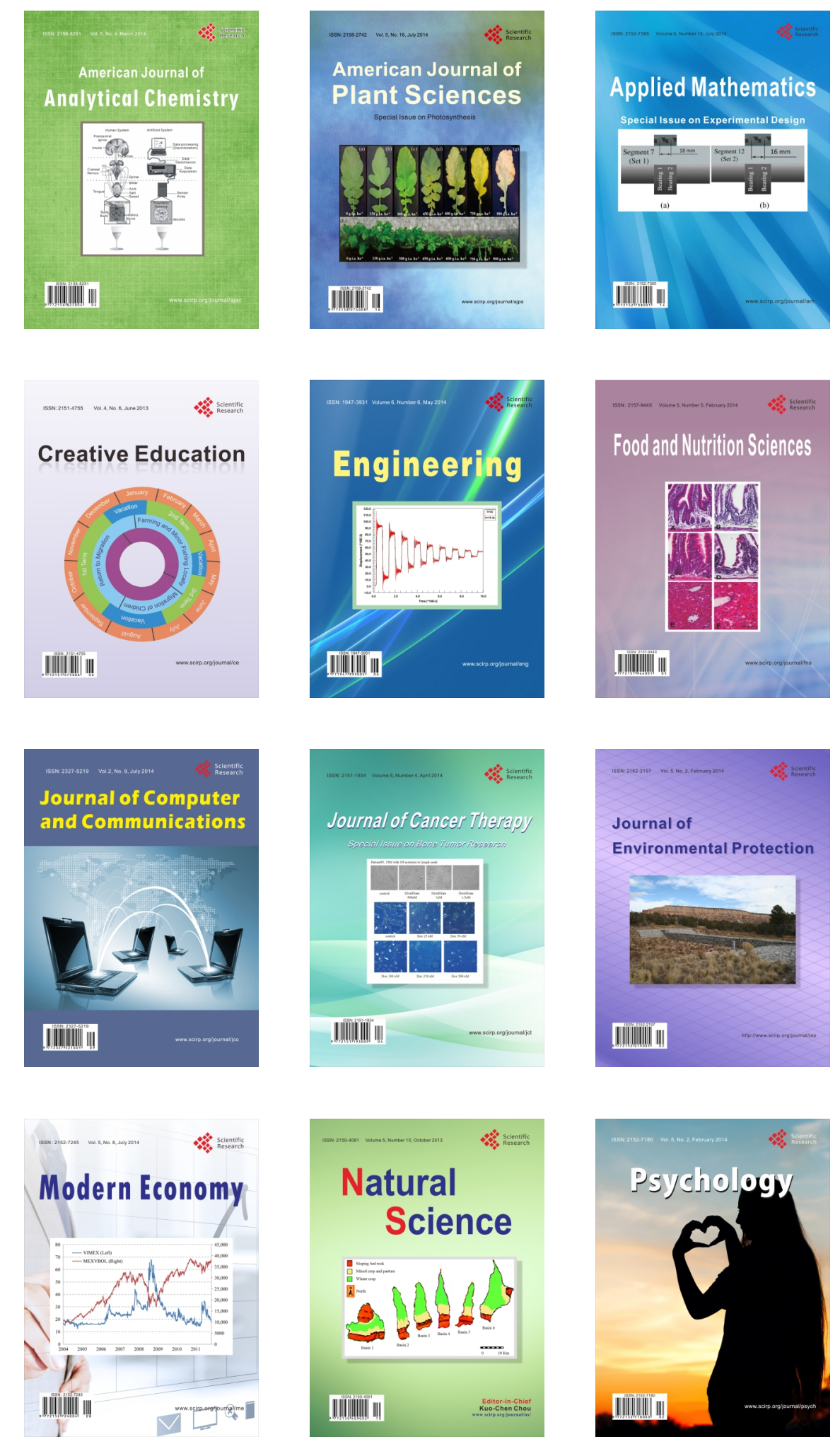